J. Dairy Sci. 96:5295-5299

http://dx.doi.org/10.3168/jds.2012-6442

(C) American Dairy Science Association ${ }^{\circledR}, 2013$.

\title{
Short communication: Evaluation of acid-insoluble ash and indigestible neutral detergent fiber as total-tract digestibility markers in dairy cows fed corn silage-based diets
}

\author{
C. Lee and A. N. Hristov ${ }^{1}$ \\ Department of Animal Science, The Pennsylvania State University, University Park 16802
}

\begin{abstract}
The objective of this experiment was to evaluate acid-insoluble ash (AIA) and indigestible NDF (iNDF) as intrinsic digestibility markers in comparison with total fecal collection (TC) in dairy cows fed corn silageand alfalfa haylage-based diets. The experiment was part of a larger experiment, which involved 8 Holstein cows $[102 \pm 28.4 \mathrm{~d}$ in milk, $26.4 \pm 0.27 \mathrm{~kg} / \mathrm{d}$ of dry matter $(\mathrm{DM})$ intake, and $43 \pm 5.3 \mathrm{~kg} / \mathrm{d}$ milk yield]. The experimental design was a replicated $4 \times 4$ Latin square with the following treatments: metabolizable protein (MP)-adequate diet $[15.6 \%$ crude protein $(\mathrm{CP})$; high-CP], MP-deficient diet (14.0\% CP; low-CP), and 2 other low-CP diets supplemented (top-dressed) with ruminally protected Lys or Lys and Met. Data for the 3 low-CP diets were combined for this analysis. Total feces were collected for 5 consecutive days during each period to estimate total-tract apparent digestibility. Digestibility was also estimated using AIA (digestion with $2 \mathrm{~N} \mathrm{HCl}$ ) and iNDF (12-d ruminal incubation in $25-\mu \mathrm{m}$-pore-size bags). Significant diet $\times$ digestibility method interactions were observed for fecal output of nutrients and digestibility. Fecal output of nutrients estimated using AIA or iNDF was lower compared with TC and fecal output of DM, organic matter, and CP tended to be higher for iNDF compared with AIA for the high-CP diet. For the low-CP diet, however, fecal output of all nutrients was lower for AIA compared with TC and was higher for iNDF compared with TC. Data from this experiment showed that, compared with TC, AIA underestimated fecal output and overestimated digestibility, particularly evident with the fiber fractions and the protein-deficient diet. Compared with TC, fecal output was overestimated and digestibility of the low-CP diet was underestimated when iNDF was used as a marker, although the magnitude of the difference was smaller compared with that for AIA. In the conditions of the current study, iNDF appeared to be a
\end{abstract}

Received December 1, 2012

Accepted May 5, 2013.

${ }^{1}$ Corresponding author: anh13@psu.edu more reliable digestibility marker than AIA in terms of detecting dietary differences in apparent digestibility of some nutrients, but significant diet $\times$ marker interactions existed that need to be considered when estimating total-tract digestibility using intrinsic markers.

Key words: acid-insoluble ash, dairy cow, digestibility, indigestible neutral detergent fiber

\section{Short Communication}

Diet digestibility is directly related to energy supply and animal performance and has been used to express energy content of feeds for ruminants (i.e., TDN; Van Soest, 1994). The standard procedure for estimating total-tract digestibility involves a balance study with total collection of feces (TC) and separation of urine (Schneider and Flatt, 1975). These types of experiments, however, are laborious and not always practical with sufficient number of animals and particularly with high-producing dairy cows. An alternative approach is to use indigestible external or internal markers (Satter et al., 1986). Acid-insoluble ash (AIA; Van Keulen and Young, 1977) and indigestible NDF (iNDF; Lippke et al., 1986) are among the various intrinsic markers that have been proposed, used, and critically evaluated (Huhtanen et al., 1994; Van Soest, 1994). Digestibility data derived using AIA, however, can be quite variable, perhaps due to a large extent to variable concentration of AIA in feeds and the ration (Van Soest, 1994). Huhtanen et al. (1994) found AIA to be the most suitable digestibility marker (compared with TC) for grass silage- or hay-based diets, followed by iNDF. We have observed significant variability in AIA concentrations in TMR, depending on diet composition and the forages used. For example, diets based on alfalfa and cereal silages had AIA concentrations of 1.4 to $1.7 \%$ (DM basis; data from Hristov et al., 2004 and 2005) compared with 0.50 to $0.56 \%$ AIA in diets based on corn silage (data from Hristov et al., 2010 and 2011). The level of concentrate feeds in the diet can also affect the accuracy of the AIA procedure (Thonney et al., 1985). As pointed out by Van Soest (1994), the combination of low AIA concentration and variability in the assay may 
preclude the usefulness of AIA as a digestibility marker in certain diets. Therefore, the objective of this study was to compare AIA and iNDF with TC for estimating total-tract apparent digestibility of nutrients in dairy cows fed corn silage- and alfalfa haylage-based diets varying in $\mathrm{CP}$ content.

Animals involved in this experiment were cared for and the experimental procedures were approved by The Pennsylvania State University Animal Care and Use Committee (IACUC no. 32656). The study was part of a larger experiment (Lee et al., 2011b) using 8 ruminally cannulated multiparous Holstein cows (average \pm SD; parity: $2.8 \pm 0.7$ lactations, DIM: $102 \pm 28.4$ d, DMI: $26.4 \pm 0.27 \mathrm{~kg} / \mathrm{d}$, milk yield: $43 \pm 5.3 \mathrm{~kg} / \mathrm{d}$, and BW: $682 \pm 47.7 \mathrm{~kg}$ ). The design of the experiment was a replicated $4 \times 4$ Latin square, with 2 concurrent squares and four 21-d periods. Treatments were an MP-adequate diet $(15.6 \% \mathrm{CP}$, high-CP; this diet met MP requirements according to NRC, 2001), MPdeficient diet $(14.0 \% \mathrm{CP}$; low-CP; this diet was about $15 \%$ MP deficient), and 2 other low-CP diets supplemented (top-dressed) with ruminally protected Lys or Lys and Met. Dietary ingredients were as reported in Lee et al. (2012b). The high-CP diet contained (DM basis) $15.6 \% \mathrm{CP}, 35.0 \% \mathrm{NDF}, 22.6 \% \mathrm{ADF}$, and $41.9 \%$ NFC. The low-CP diet contained 14.0, 33.1, 21.3, and $44.0 \%$, respectively. Feeding was as specified by Lee et al. (2012b) and milking was twice daily at 0500 and $1700 \mathrm{~h}$. During the last $9 \mathrm{~d}$ of each experimental period, cows were moved to metabolic stalls, in which total fecal and urine collections were conducted for $5 \mathrm{~d}$, following $4 \mathrm{~d}$ of adaptation to the stalls. Feces were collected in metal containers positioned behind the metabolic units and transferred, weighed, and sampled once daily (at $0600 \mathrm{~h}$ ). Urine was collected through urinary catheters as described by Hristov et al. (2010).

Feed intake and refusals were monitored daily and samples of TMR and refusals were collected twice weekly, processed, composited, and the composite samples were analyzed for chemical composition as described by Lee et al. (2012b) and digestibility markers. Diets, refusals, and feces were analyzed for AIA and iNDF according to Van Keulen and Young (1977; using $2 \mathrm{~N} \mathrm{HCl}$ ) and as described by Lee et al. (2012b; 12-d ruminal incubation in $25-\mu \mathrm{m}$-pore-size bags), respectively. Dry matter was determined by drying for $48 \mathrm{~h}$ at $65^{\circ} \mathrm{C}$ in a forced-air oven. Samples were ground in a Wiley mill (A. H. Thomas Co., Philadelphia, PA) through a 1-mm sieve before analysis. As the 3 MP-deficient diets in the main trial were based on the same basal TMR and only differed in the ruminally protected amino acids (top-dressed; as in Lee et al., 2012b), data for these diets were combined for the chemical analyses (i.e., representing the low-CP diet). The average (across experimental periods) AIA content (DM basis; SD in parentheses) of the high-CP and low-CP diets, high-CP and low-CP refusals, and high-CP and low-CP feces was as follows: 0.32 (0.053) and $0.29(0.043), 0.31(0.02)$ and $0.35(0.02)$, and 0.98 $(0.13)$ and $0.94 \%(0.13)$, respectively. Two ruminally cannulated lactating dairy cows were used for the iNDF analysis. Cows were fed a diet based on corn silage and alfalfa haylage and also contained grass hay, ground corn grain, heated whole soybeans, canola meal, bakery by-product meal, a molasses-based product, cottonseed hulls, a slow-release urea source (Optigen; Alltech Inc., Nicholasville, KY), and a mineral and vitamin premix. The average iNDF content (SD) of the high-CP and low-CP diets, high-CP and low-CP refusals, and high$\mathrm{CP}$ and low-CP feces was as follows: $12.4(0.94)$ and 14.3 (1.03), $14.2(0.74)$ and 13.7 (0.34), and 36.5 (1.72) and $36.1 \%$ (1.71), respectively.

Fecal excretion and total-tract apparent digestibility of dietary nutrients were calculated based on gravimetric measurements (TC) or concentrations of iNDF and AIA in TMR, refusals, and feces (Schneider and Flatt, 1975). Data were analyzed using PROC MIXED of SAS (2003; SAS Institute Inc., Cary, NC). Fecal output and total-tract digestibility data were analyzed by ANOVA Latin square, with cow, square, experimental period, digestibility method (TC, AIA, or iNDF), and diet (high-CP and low-CP) as class variables and period and method $\times$ diet in the model statement. Cow within square $\times$ period $\times$ method $\times$ diet was the error term. Square and cow within square were random effects, whereas all other factors were fixed. Orthogonal contrasts were used to compare digestibility methods (TC vs. the average of AIA and iNDF and iNDF vs. AIA). Statistical differences were declared at $P<0.05$. Differences between treatments at $0.05<P<0.10$ were considered as a trend toward significance. Data are presented as least squares means (method $\times$ diet).

With the high-CP diet, fecal DM output estimated by markers was lower $(P=0.02)$ than TC (Table 1$)$. This resulted in lower $(P \leq 0.03)$ fecal output estimates for all nutrients when the marker methods were used. The difference was about $15 \%$ for AIA compared with TC and 6 to $7 \%$ for iNDF compared with TC. Fecal excretion of DM and all other nutrients was lower $(P$ $\leq 0.007$; $P$-values for individual marker vs. TC comparisons are not shown in Table 1) for AIA compared with TC. Fecal excretion of DM and all nutrients was either numerically lower $(P=0.11)$ or tended to be lower $(P \leq 0.09)$ for AIA compared with iNDF. Fecal output of all nutrients was similar $(P \geq 0.22)$ between iNDF and TC. As a result of the lower fecal excretion, digestibility estimates for all nutrients for the high-CP diet were higher $(P \leq 0.01)$ for the marker methods compared with TC. The difference was from 4 (DM/ 
$\mathrm{OM})$ to $10 \%(\mathrm{ADF})$ for iNDF, and from 8 (OM) to $20 \%$ (ADF) for AIA, compared with TC. Digestibility was similar $(P \geq 0.12)$ between iNDF and AIA, except digestibility of DM and OM, which tended $(P=0.07)$ to be higher for AIA. Digestibility of all nutrients was higher $(P \leq 0.004)$ for AIA than TC. Compared with TC, digestibility coefficients estimated using iNDF as a marker were either not different (only numerically higher; $P \geq 0.15)$ or tended to be higher $(P=0.09)$ in the case of DM and OM.

With the low-CP diet, marker-estimated fecal output of all nutrients was different $(P \leq 0.02)$ from nutrient outputs estimated by TC (Table 1 ). Fecal output of all nutrients was 18 to $19 \%$ lower for AIA compared with TC $(P<0.001)$, but was from $6(\mathrm{CP})$ to $9 \%(\mathrm{ADF})$ higher for iNDF compared with TC $(P \leq 0.01)$. Fecal output of nutrients was about $25 \%$ lower $(P<0.001)$ for AIA compared with iNDF. The marker methods produced different $(P \leq 0.01)$ digestibility estimates compared with TC. Using AIA as a digestibility marker produced higher $[12(\mathrm{DM} / \mathrm{OM})$ to $26 \%(\mathrm{NDF}) ; P<$ 0.001] digestibility coefficients compared with TC. Di- gestibility estimates were, however, lower [from 5 (DM/ $\mathrm{OM}$ ) to $11 \%$ (ADF); $P \leq 0.005]$ for iNDF compared with TC. Digestibility of all nutrients was from 17 $(\mathrm{OM})$ to $34 \%(\mathrm{NDF})$ higher $(P<0.001)$ for AIA than iNDF.

The diets used in this experiment differed in ingredient composition because decreasing dietary $\mathrm{CP}$ and $\mathrm{MP}$ supply for the low-CP diet was achieved by decreasing the inclusion rate of soybean meal and whole roasted soybeans and increasing that of corn grain. This resulted in lower NDF and higher NFC (starch) content of the low-CP diet. The low-CP diet also had greater iNDF content compared with the high-CP diet (about $15 \%$ greater), whereas the AIA content was similar between the diets.

Overall recovery of marker in fecal DM was similar between AIA and iNDF $(86.9 \pm 0.66$ and $88.7 \% \pm$ 0.65 , respectively). The contrasting effects of marker on fecal excretion of nutrients and digestibility between diets arose from differences in marker concentrations in TMR and feces. Due to the greater fecal:TMR AIA ratios, particularly for the low-CP diet (average of

Table 1. Fecal output and total-tract apparent digestibility (LSM) of dietary nutrients determined by total fecal collection (TC), indigestible NDF (iNDF), or acid-insoluble ash (AIA) in lactating dairy cows ${ }^{1}$

\begin{tabular}{|c|c|c|c|c|c|c|}
\hline \multirow[b]{2}{*}{ Item } & \multicolumn{3}{|c|}{ Digestibility method } & \multirow[b]{2}{*}{$\mathrm{SEM}^{2}$} & \multicolumn{2}{|c|}{ Contrast, ${ }^{3} P$-value } \\
\hline & $\mathrm{TC}$ & iNDF & AIA & & Marker/TC & iNDF/AIA \\
\hline \multirow{2}{*}{\multicolumn{7}{|c|}{ Fecal output, $\mathrm{kg} / \mathrm{d}$}} \\
\hline & \multicolumn{6}{|c|}{ High-CP diet } \\
\hline $\mathrm{DM}$ & 9.9 & 9.3 & 8.4 & 0.34 & 0.02 & 0.07 \\
\hline $\mathrm{OM}$ & 8.9 & 8.3 & 7.6 & 0.32 & 0.02 & 0.08 \\
\hline NDF & 4.7 & 4.4 & 4.0 & 0.22 & 0.02 & 0.11 \\
\hline $\mathrm{ADF}$ & 3.4 & 3.2 & 2.9 & 0.16 & 0.03 & 0.11 \\
\hline $\mathrm{CP}$ & 1.6 & 1.5 & 1.4 & 0.06 & 0.02 & 0.09 \\
\hline \multicolumn{7}{|c|}{ Low-CP diet } \\
\hline DM & 10.3 & 11.0 & 8.3 & 0.19 & 0.01 & $<0.001$ \\
\hline $\mathrm{OM}$ & 9.2 & 9.9 & 7.5 & 0.19 & 0.01 & $<0.001$ \\
\hline $\mathrm{NDF}$ & 4.9 & 5.3 & 4.0 & 0.17 & 0.02 & $<0.001$ \\
\hline $\mathrm{ADF}$ & 3.4 & 3.7 & 2.8 & 0.12 & 0.02 & $<0.001$ \\
\hline $\mathrm{CP}$ & 1.6 & 1.7 & 1.3 & 0.03 & 0.02 & $<0.001$ \\
\hline \multicolumn{7}{|c|}{ Apparent digestibility, \% } \\
\hline \multicolumn{7}{|c|}{ High-CP diet } \\
\hline $\mathrm{DM}$ & 61.6 & 64.2 & 67.1 & 1.37 & 0.004 & 0.07 \\
\hline $\mathrm{OM}$ & 62.9 & 65.4 & 68.2 & 1.39 & 0.004 & 0.07 \\
\hline $\mathrm{NDF}$ & 47.1 & 50.9 & 54.5 & 1.84 & 0.01 & 0.16 \\
\hline $\mathrm{ADF}$ & 41.8 & 45.9 & 50.0 & 1.93 & 0.01 & 0.13 \\
\hline $\mathrm{CP}$ & 59.8 & 62.6 & 65.6 & 1.69 & 0.01 & 0.12 \\
\hline \multicolumn{7}{|c|}{ Low-CP diet } \\
\hline $\mathrm{DM}$ & 61.0 & 58.0 & 68.4 & 1.02 & 0.005 & $<0.001$ \\
\hline $\mathrm{OM}$ & 62.2 & 59.4 & 69.4 & 1.06 & 0.004 & $<0.001$ \\
\hline $\mathrm{NDF}$ & 46.0 & 41.9 & 56.3 & 1.12 & 0.01 & $<0.001$ \\
\hline $\mathrm{ADF}$ & 41.9 & 37.5 & 53.0 & 1.18 & 0.01 & $<0.001$ \\
\hline $\mathrm{CP}$ & 56.4 & 53.1 & 64.6 & 1.27 & 0.01 & $<0.001$ \\
\hline \multicolumn{7}{|c|}{$\begin{array}{l}{ }^{1} \text { Average intake of DM, OM, NDF, ADF, and CP during the trial was (SD in parentheses) } 25.7(3.69), 23.9 \\
(3.48), 9.0(1.76), 5.7(1.09) \text {, and } 4.1(0.55) \mathrm{kg} / \mathrm{d} \text { and } 26.6(2.24), 24.7(2.08), 9.1(0.81), 5.9(0.57) \text {, and } 3.8 \\
(0.31) \mathrm{kg} / \mathrm{d} \text { for the high-CP and low-CP diets, respectively. } \\
{ }^{2} \mathrm{n}=87 ; \mathrm{n} \text { represents the number of observations used in the statistical analysis. } \\
{ }^{3} P \text {-value for orthogonal contrasts: marker/TC = average of iNDF and AIA versus TC; iNDF/AIA = iNDF } \\
\text { versus AIA. }\end{array}$} \\
\hline
\end{tabular}


3.23) than fecal:TMR iNDF ratios (2.52), estimated fecal DM excretion was considerably lower for AIA than iNDF. These differences in fecal output resulted in greater nutrient digestibilities with AIA than iNDF for the low-CP diet and similar but more subtle trends for the high-CP diet.

The differences in fecal output and digestibility between diets estimated with iNDF were mainly caused by the greater iNDF content of the low-CP diet compared with the high-CP diet. The reason for the different iNDF content of the 2 diets is unclear. The low-CP diet had in fact lower NDF and ADF content than the high-CP diet and both diets were incubated simultaneously in the cows. It is possible that the 2 diets created a different microenvironment within the in situ bags, which may have caused differences in fiber digestibility and, thus, iNDF concentration. It has been shown that microbial composition, specifically cellulolytic bacteria counts (Meyer and Mackie, 1986), and enzymatic activities (Huhtanen and Khalili, 1992; Huhtanen et al., 1998) are considerably lower within nylon bags incubated in the rumen than in the surrounding ruminal contents. The low-CP diet contained slightly greater NFC content (due to increased corn grain inclusion) than the high-CP diet, which might have caused inhibition of fiber degradation with the former diet (Firkins, 1997). The low CP and RDP content of a similar diet did cause decreased total-tract apparent digestibility in the companion in vivo study (Lee et al., 2012b). To test the possibility that the microenvironment within the bag may affect fiber degradability (i.e., iNDF content of in situ residues), a pilot experiment was conducted. The experiment used 2 ruminally cannulated cows and the iNDF procedure was as described in the Materials and Methods. Ground through a 2-mm screen, alfalfa hay and corn grain were incubated in situ as single feeds or in mixes of 80:20, 60:40, and 40:60 (alfalfa hay and corn grain, respectively). Actual iNDF concentrations on the hay:grain mixes were expressed as percentages of iNDF, calculated based on iNDF content of the 2 individual feeds $[19.7 \%(\mathrm{SD}=1.84)$ alfalfa hay and $2.9(\mathrm{SD}=0.75)$ corn grain]. Data were analyzed with PROC Mixed of SAS (cow was a random effect). The average overestimation of iNDF for 20, 40, and $60 \%$ substitution of alfalfa with grain was $4.0,7.0$, and $8.6 \%(\mathrm{SEM}=4.16 ; P=0.04)$, which indicated gradual increase in the overestimation of iNDF with increasing the proportion of grain in the feed mix incubated in situ. This observation supports our hypothesis that the microenvironment in the in situ bag may affect fiber degradability and iNDF estimates. Although no direct evidence exists that the different chemical composition of the TMR samples incubated in situ caused inhibited fiber fermentation within the bag and affected iNDF estimates in the current study, based on data from the pilot study, this possibility cannot be excluded.

The purpose of a digestibility marker is to provide reliable digestibility estimates for nutrients in absolute terms or when dietary treatments are compared within experiment. In the main experiment, no differences existed in total-tract digestibility of most nutrients when determined using TC $(P \geq 0.13)$, except $\mathrm{CP}$ digestibility tended to be decreased $(P=0.08)$ with the low-CP diet (Lee et al., 2011b). With iNDF as digestibility marker, however, estimated digestibilities of all nutrients were lower $(P<0.001)$ with the low-CP than the high-CP diet. These trends were similar to the depressed totaltract digestibilities, particularly of the fiber fraction, observed for low-CP, MP-deficient diets in long-term continuous design trials, in which iNDF was used as a digestibility marker (Lee et al., 2011a, 2012a,b). In contrast, digestibilities of all nutrients, except $\mathrm{CP}(P$ $=0.85)$ tended to be or were greater $(P=0.06$ to 0.01) for the low-CP compared with the high-CP diet when AIA was the digestibility marker in the current experiment. Thus, AIA failed to detect the significant reduction of $\mathrm{CP}$ digestibility observed with the low-CP compared with the high-CP diet when digestibility was estimated using TC.

Acid-insoluble ash has been used as digestibility marker with various animal species (Block et al., 1981; van Leeuwen et al., 1996; Bergero et al., 2009) and was found to provide reliable digestibility estimates in cattle fed grass silage- or hay-based diets by Huhtanen et al. (1994), but has been shown to be problematic with forages, particularly silages, contaminated with soil during harvest (Wallsten and Martinsson, 2009). Another important consideration with AIA is the ingredient composition of the diet studied. As pointed out by Thonney et al. (1985), AIA is less reliable as digestibility marker with high-grain diets due to their low AIA concentration. Indeed, grass silage samples were reported to have about 3 times greater concentration of AIA than grains (data from Kuoppala et al., 2008; P. Huhtanen, Swedish University of Agricultural Sciences, Umeå, Sweden, personal communication). Udén (1984) also indicated greater variability with AIA compared with TC and inability of AIA to detect small differences in diet digestibility in dairy cows. Data from the present experiment showed that, compared with TC, AIA underestimated fecal output and overestimated digestibility, particularly evident with the fiber fractions, of a corn silage and alfalfa haylage-based, proteindeficient diet. Indigestible NDF (determined by various in situ or in vitro procedures) has been reported to be a reliable digestibility marker in controlled animal experiments (Lippke et al., 1986; Huhtanen et al., 1994; Huhtanen et al., 2006), or recently in commercial dairy 
herds (Schalla et al., 2012). In the current study, however, fecal output was overestimated and digestibility of the low-CP diet was underestimated compared with TC when iNDF was used as a marker, although the magnitude of the difference was smaller than with AIA. Both AIA and iNDF tended to underestimate fecal nutrient outputs but yielded similar to TC digestibility coefficients with the high-CP diet. Overall, iNDF appeared to be a more reliable digestibility marker than AIA in terms of detecting dietary differences in apparent digestibility of some nutrients, but significant diet $\times$ digestibility marker interactions were observed that need to be considered when estimating total-tract digestibility using intrinsic markers.

\section{REFERENCES}

Bergero, D., C. Préfontaine, N. Miraglia, and P. G. Peiretti. 2009. A comparison between the $2 \mathrm{~N}$ and $4 \mathrm{~N} \mathrm{HCl}$ acid-insoluble ash methods for digestibility trials in horses. Animal 3:1728-1732.

Block, E., L. H. Kilmer, and L. D. Muller. 1981. Acid insoluble ash as a marker of digestibility for sheep fed corn plants or hay and for lactating dairy cattle fed hay ad libitum. J. Anim. Sci. 52:11641169.

Firkins, J. L. 1997. Effects of feeding nonforage fiber sources on site of fiber digestion. J. Dairy Sci. 80:1426-1437.

Hristov, A. N., K. L. Grandeen, J. K. Ropp, and M. A. McGuire. 2004. Effect of sodium laurate on ruminal fermentation and utilization of ruminal ammonia nitrogen for milk protein synthesis in dairy cows. J. Dairy Sci. 87:1820-1831.

Hristov, A. N., C. Lee, T. Cassidy, M. Long, K. Heyler, B. Corl, and R. Forster. 2011. Effects of lauric and myristic acids on ruminal fermentation, production, and milk fatty acid composition in lactating dairy cows. J. Dairy Sci. 94:382-395.

Hristov, A. N., J. K. Ropp, K. L. Grandeen, S. Abedi, R. P. Etter, A. Melgar, and A. E. Foley. 2005. Effect of carbohydrate source on ammonia utilization in lactating dairy cows. J. Anim. Sci. 83:408-421.

Hristov, A. N., G. Varga, T. Cassidy, M. Long, K. Heyler, K. R. Karnati, B. Corl, C. J. Hovde, and I. Yoon. 2010. Effect of yeast culture on ruminal fermentation and nutrient utilization in dairy cows. J. Dairy Sci. 93:682-692.

Huhtanen, P., S. Ahvenjärvi, M. R. Weisbjerg, and P. Nørgaard. 2006. Digestion and passage of fiber in ruminants. Pages 87-135 in Ruminant Physiology. K. Sejrsen, T. Hvelplund, and M. O. Nielsen, ed. Wageningen Acad. Publ., Wageningen, the Netherlands.

Huhtanen, P., K. Kaustell, and S. Jaakkola. 1994. The use of internal markers to predict total digestibility and duodenal flow of nutrients in cattle given six different diets. Anim. Feed Sci. Technol. 48:211-227.

Huhtanen, P., and H. Khalili. 1992. The effect of sucrose supplements on particle-associated carboxymethylcellulase (EC 3.2.1.4) and xylanase (EC 3.2.1. 8) activities in cattle given grass-silage-based diet. Br. J. Nutr. 67:245-255.

Huhtanen, P., A. Vanhatalo, and T. Varvikko. 1998. Enzyme activities of rumen particles and feed samples incubated in situ with differing types of cloth. Br. J. Nutr. 79:161-168.

Kuoppala, K., M. Rinne, J. Nousiainen, and P. Huhtanen. 2008. The effect of cutting time of grass silage in primary growth and re- growth and the interactions between silage quality and concentrate level on milk production of dairy cows. Livest. Sci. 116:171-182.

Lee, C., A. N. Hristov, T. W. Cassidy, K. S. Heyler, H. Lapierre, G. A. Varga, M. J. de Veth, R. A. Patton, and C. Parys. 2012a. Rumenprotected lysine, methionine, and histidine increase milk protein yield in dairy cows fed a metabolizable protein-deficient diet. J. Dairy Sci. 95:6042-6056.

Lee, C., A. N. Hristov, K. S. Heyler, T. W. Cassidy, H. Lapierre, G. A. Varga, and C. Parys. 2012b. Effects of metabolizable protein supply and amino acids supplementation on nitrogen utilization, milk production, and ammonia emissions from manure in dairy cows. J. Dairy Sci. 95:5253-5268.

Lee, C., A. N. Hristov, K. S. Heyler, T. W. Cassidy, M. Long, B. A. Corl, and S. K. R. Karnati. 2011a. Effects of dietary protein concentration and coconut oil supplementation on nitrogen utilization and production in dairy cows. J. Dairy Sci. 94:5544-5557.

Lee, C., A. N. Hristov, H. Lapierre, T. Cassidy, K. Heyler, G. A. Varga, and C. Parys. 2011b. Effect of dietary protein level and rumen-protected amino acid supplementation on dietary amino acid apparent digestibility and recovery in milk in lactating dairy cows. J. Dairy Sci. 94(Suppl. 1):689. (Abstr.)

Lippke, H., W. C. Ellis, and B. F. Jacobs. 1986. Recovery of indigestible fiber from feces of sheep and cattle on forage diets. J. Dairy Sci. 69:403-412.

Meyer, J. H. F., and R. I. Mackie. 1986. Microbial evaluation of the intraruminal in sacculus digestion technique. Appl. Environ. Microbiol. 51:622-629.

NRC. 2001. Nutrient Requirements of Dairy Cattle. 7th rev. ed. Natl. Acad. Sci., Washington, DC.

Satter, L. D., D. K. Combs, J. M. Lopez-Guiza, and W. F. Nelson. 1986. Use of markers for measurement of feed digestibility in ruminants. Pages 469-484 in Nuclear and Related Techniques in Animal Production and Health. International Atomic Energy Agency, Vienna, Austria.

Schalla, A., L. Meyer, Z. Meyer, S. Onetti, A. Schultz, and J. Goeser. 2012. Hot topic: Apparent total-tract nutrient digestibilities measured commercially using 120 -hour in vitro indigestible neutral detergent fiber as a marker are related to commercial dairy cattle performance. J. Dairy Sci. 95:5109-5114.

Schneider, B. H., and W. P. Flatt. 1975. The Evaluation of Feeds Through Digestibility Experiments. University of Georgia Press, Athens.

Thonney, M. L., B. A. Palhof, M. R. DeCarlo, D. A. Ross, N. L. Firth, R. L. Quaas, D. J. Perosio, D. J. Duhaime, S. R. Rollins, and A. Y. M. Nour. 1985. Sources of variation of dry matter digestibility measured by the acid insoluble ash marker. J. Dairy Sci. 68:661-668.

Udén, P. I. 1984. Digestibility and digesta retention in dairy cows receiving hay or silage at varying concentrate levels. Anim. Feed Sci. Technol. 11:279-291.

Van Keulen, J., and B. A. Young. 1977. Evaluation of acid-insoluble ash as a natural marker in ruminant digestibility studies. J. Anim. Sci. 44:282-287.

van Leeuwen, P., A. Veldman, S. Boisen, K. Deuring, G. J. M. Van Kempen, G. B. Derksen, M. W. A. Verstegen, and G. Schaafsma. 1996. Apparent ileal dry matter and crude protein digestibility of rations fed to pigs and determined with the use of chromic oxide $\left(\mathrm{Cr}_{2} \mathrm{O},\right)$ and acid-insoluble ash as digestive markers. Br. J. Nutr. 76:551-562.

Van Soest, P. J. 1994. Nutritional Ecology of the Ruminant. Cornell University Press, Ithaca, NY.

Wallsten, J., and K. Martinsson. 2009. Effects of maturity stage and feeding strategy of whole crop barley silage on intake, digestibility and milk production in dairy cows. Livest. Sci. 121:155-161. 